\title{
CADMIUM AND COPPER SORPTION IN A CLAYEY CHERNOZEM SOIL
}

\section{Annette Madelene Dancila ${ }^{1}$, Cristina Modrogan ${ }^{1}$, Cristina Orbeci ${ }^{1}$, Oanamari Daniela} Orbulet $^{1}$

\author{
${ }^{1}$ Politehnica University of Bucharest, Department of Analytical Chemistry and \\ Environmental Engineering, str. Polizu, nr.1-7, Romania, Bucharest, \\ dancila.madelene@yahoo.com; c_modrogan@yahoo.com; \\ cristina27ccc@yahoo.com; oanamari2001@yahoo.com
}

\begin{abstract}
The wastes used to amend soils sometimes have high concentrations of metals such as cadmium $\left(\mathrm{Cd}^{2+}\right)$ and cooper $\left(\mathrm{Cu}^{2+}\right)$. To determine the capacity of soils to retain these metals, the sorption capacities of different mine soils with and without reclamation treatments (tree vegetation and waste amendment) for $\mathrm{Cd}^{2+}$ and $\mathrm{Cu}^{2+}$ in individual and competitive situations were evaluated using the batch sorption technique. The untreated settling pond soil had low capacity for $\mathrm{Cd}^{2+}$ and $\mathrm{Cu}^{2+}$ retention. The site amended with wastes (sewage sludges and paper mill residues) increased the sorption capacity; most probably because of the higher concentrations of soil components with high retention capacity such as carbon and clay fraction. We can conclude that, despite the possible additions of $\mathrm{Cd}^{2+}$ and $\mathrm{Cu}^{2+}$ from wastes to degraded soils, sewage sludges and paper mill residues have a high sorption capacity that would prevent the metals from being in a mobile form.
\end{abstract}

Keywords: cadmium, cooper, heavy metals, retention, soil

\section{Introduction}

Rapid industrialization, urbanization, geological erosion and natural calamities are the common factors that lead to the discharge of heavy metal ions directly into natural water resources. Heavy metals including $\mathrm{Cd}^{2+}, \mathrm{Cr}^{3+}, \mathrm{As}^{3+}, \mathrm{Pb}^{2+}, \mathrm{Hg}^{2+}$, etc. are considered to be high risk for humans, animals and plants due to their toxic and ill effect. The heavy metal contamination is a serious problem to the environment, because the anthropogenic activities from mining, processing and applications of these metals have increased enormously during the past few decades and have become a challenge for life on earth. Hence their removal/remediation has become all the more necessary. Over a few years, the discarding solid and/or liquid waste products containing heavy metals emanating from the industrial processes has received a lot of attention, and consequently legislation for the protection of the environment has gradually become more rigid [1],[2], [4]-[6].

Heavy metals are particularly problematic because, unlike most organic contaminants, they are non-biodegradable and can accumulate in living tissues, posing great threat to both human health and ecological environment [3-10]. The most common heavy metals mainly include mercury, cadmium, lead, chromium, arsenic, zinc, copper, nickel, cobalt, etc. These metal ions can cause toxicities and serious side effects toward human health.

$\mathrm{Cd}^{2+}$ and $\mathrm{Cu}^{2+}$ are the major pollutants that contaminate farm lands near mines,especially copper mines, and the mobility and bioavailability of these pollutants 
are of great concern to China [11],[12], that is the reason for the present study focused on paddy soils close to copper mines and contaminated with $\mathrm{Cd}$ and $\mathrm{Cu}$. Authors sought to find out whether biochars derived from two sources (hardwood and corn straw) can continuously reduce the availability of $\mathrm{Cd}$ and $\mathrm{Cu}$ in soil and their uptake by rice. The oxidative aging of biochars under acid conditions was simulated in the laboratory to gain insights into the aging process of two biochars. Specifically, the study [13] compared the effect of two biochars on soil properties, on the mobility $\mathrm{Cd}$ and $\mathrm{Cu}$ in soil, and on their uptake by rice plants over 3 years and [14] determined the variations in the surface properties of the two biochars as a result of simulated aging. For example, copper has universally been considered to be very toxic at high concentration. It can cause copper poisoning in humans such as gastrointestinal problems, kidney damage, hair loss, nausea, anemia, hypoglycemia, severe headaches and even death [4], [6]. Cadmium is a toxic heavy metal of significant environmental and occupational concern. It has been identified as a human carcinogen and teratogen substance severely impacting lungs, kidneys, liver and reproductive organs [3], [5], [15]-[19].

An experimental study was performed, putting in evidence the capacity of a certain type of soil (clayey chernozem) to retain these metals. In order to establish the degree of metals retention in the soil, a large number of analyses must be performed. If the main factors influencing the retention of these metals in the soil are known (the soil profile, the concentration of metals, the contact time between the applied metals and the soil), the number of experiments can be reduced by applying a simulation by means of artificial neural networks.

\section{Materials and Methods (or Experimental)}

Prior to experiments, was performed a soil characterisation. The clayey levigated chernozem, although they are rich soils, because of their less favourable physical properties, give lower productions compared to the typical levigated chernozem. The caracteristics of the used soil are provided in the tables 1 to 2.

Table 1 Data regarding the soil texture [20]

\begin{tabular}{|c|c|c|c|}
\hline \multicolumn{4}{|c|}{ Texture } \\
\hline \multicolumn{4}{|c|}{ Grit, $m m$} \\
\hline $2.0-0.2$ & $2.0-1.0$ & $1.0-0.5$ & $0.5-1.0$ \\
\hline $2.6 \%$ & $0.3 \%$ & $0.5 \%$ & $1.8 \%$ \\
\hline \multicolumn{4}{|c|}{ Fine sand, $\mathrm{mm}$} \\
\hline $0.2-0.02$ & $0.2-0.1$ & $0.1-0.05$ & $0.05-0.02$ \\
\hline $32.5 \%$ & $4.1 \%$ & $3.2 \%$ & $25.2 \%$ \\
\hline Dust, $\mathrm{mm}$ & \multicolumn{2}{|c|}{ Clay, $\mathrm{mm}$} & Carbonates \\
\hline $0.02-0.002$ & $<0.002$ & $<0.01$ & \\
\hline $31 \%$ & $33.9 \%$ & $49.3 \%$ & $0 \%$ \\
\hline
\end{tabular}

Table 2. Soil microelement contents [20]

\begin{tabular}{|l|l|l|l|l|l|l|l|l|}
\hline $\mathbf{Z n}$ & $\mathbf{C u}$ & $\mathbf{F e}$ & $\mathbf{M n}$ & $\mathbf{P b}$ & $\mathbf{C o}$ & $\mathbf{N i}$ & $\mathbf{C r}$ & $\mathbf{C d}$ \\
\hline $\mathrm{mg} / \mathrm{kg}$ & 27.4 & 25671 & 740 & 21.7 & 9.7 & 55.8 & 13.2 & 0.01 \\
\hline 80.2 & 27.4 &
\end{tabular}

The purpose of this paper is to study the kinetics of the metals retention $\left(\mathrm{Cd}^{2+}\right.$ and $\left.\mathrm{Cu}^{2+}\right)$ on 1 clayey chernozem soil type profiles $(0$ to $10 \mathrm{~cm})$ at mass ratio $1: 5$ soil: water. 
The soil was dried in the drying chamber at $40^{\circ} \mathrm{C}$ for $30 \mathrm{~min}$. The kinetic study consisted in putting $1 \mathrm{~g}$ of soil in contact with $50 \mathrm{~cm}^{3}$ of solution $\left(\mathrm{CdCl}_{2}\right.$, for the $\mathrm{Cd}^{2+}, \mathrm{CuCl}_{2}$ for the $\mathrm{Cu}^{2+}$ ) having the same concentration for different contact time intervals. The analyses

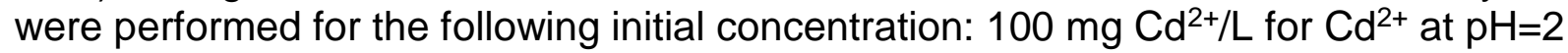
and $\mathrm{pH}=5.18$ and $100 \mathrm{mg} \mathrm{Cu}{ }^{2+} / \mathrm{L}$ for $\mathrm{Cu}^{2+}$ at $\mathrm{pH}=2$ and $\mathrm{pH}=5.18$. The glasses were covered with a foil, in order to prevent the evaporation, and shaken at different time intervals $(0,2.5,5,10,15,20,30,60,90$ and 120 minutes) at the temperature of $20^{\circ} \mathrm{C} \pm 2^{\circ} \mathrm{C}$. The shaking was performed by means of a Heidolph Unimax shaker at 300 rotations/minute. At the end of the shaking period, the samples were filtered under vacuum and brought in $50 \mathrm{~mL}$ measuring flask. Samples were collected from the filtrate in order to perform the analysis (the determination of the $\mathrm{Cu}^{2+}$ and $\mathrm{Cd}^{2+}$ from the solution was performed using Atomic absorption spectrometry (AAS).

\section{Results and Discussion}

In this paper, the adsorption kinetics was studied by recording variation in time of $\mathrm{Cd}^{2+}$ and $\mathrm{Cu}^{2+}$ in aqueous phase. This way, integral kinetic curves concentration vs. time $C(t)$ were drawn.

To determine variation in time of $\mathrm{Cd}^{2+}$ and $\mathrm{Cu}^{2+}$ concentration in soil, a mass balance equation was used [21],[22]:

$q_{t}=\frac{V \cdot\left(c_{0}-c_{t}\right)}{m_{R}}$

where: $\quad V$ - volume of aqueous phase $(\mathrm{mL}) ; c_{0}-\mathrm{Cd}^{2+} / \mathrm{Cu}^{2+}$ concentration in aqueous phase before phase contact $(\mathrm{mg} / \mathrm{L}) ; \mathrm{c}_{t}-\mathrm{Cd}^{2+} / \mathrm{Cu}^{2+}$ concentration in aqueous phase at a contact time $t(\mathrm{mg} / \mathrm{L}) ; q_{t}-\mathrm{Cd}^{2+} / \mathrm{Cu}^{2+}$ concentration in soil at a contact time $t(\mathrm{mg} / \mathrm{kg}) ; m_{R}-$ soil mass $(\mathrm{g})$.

By using Eq. (1), variation in time of $\mathrm{Cd}^{2+} / \mathrm{Cu}^{2+}$ concentration was determined, in form of kinetic integral curves $q(t)$. In order to calculate the $\mathrm{Cd}^{2+} / \mathrm{Cu}^{2+}$ retention rate in soil, expressed as differential kinetic curves $q(t)$, were used three kinetic models: the pseudo- $1^{\text {st }}$ order and the pseudo- $2^{\text {nd }}$ order model.

Differential form of the pseudo- $1^{\text {st }}$ order model is expressed according to equation (2):

$$
\frac{d q_{t}}{d t}=k_{1}\left(q^{*}-q_{t}\right)
$$

where $q_{t}-\mathrm{Cd}^{2+} / \mathrm{Cu}^{2+}$ concentration in the reactive fraction of soil at moment " $t$ ";

$q^{\star}-\mathrm{Cd}^{2+} / \mathrm{Cu}^{2+}$ concentration in the reactive fraction of soil at equilibrium;

$k_{1}$ - constant of the pseudo- ${ }^{\text {st }}$ order kinetic model $\left(\mathrm{min}^{-1}\right)$.

Considering the boundary conditions $t=0 \rightarrow q=q_{0}$, and at the moment $t \rightarrow q=q_{t}$, results the integral form of the pseudo- $1^{\text {st }}$ kinetic order:

$\ln \left(\frac{q^{*}-q_{t}}{q^{*}-q_{0}}\right)=-k_{1} t$

which can be expressed in the linear form

$\ln \left(q^{*}-q_{t}\right)=\ln \left(q^{*}-q_{0}\right)-k_{1} t$

The pseudo $1^{\text {st }}$ model parameters were calculated by linear regression, considering the variable changes in equation (3') $x=t, y=\ln \left(q^{*}-q_{t}\right)$.

Differential form of the pseudo-2 ${ }^{\text {nd }}$ order model is expressed according to equation (4): 
$\frac{d q_{t}}{d t}=k_{2}\left(q^{*}-q_{t}\right)^{2}$

where $q_{t}-\mathrm{Cd}^{2+} / \mathrm{Cu}^{2+}$ concentration in the reactive fraction of soil at moment " $t$ ";

$q^{*}-\mathrm{Cd}^{2+} / \mathrm{Cu}^{2+}$ concentration in the reactive fraction of soil at equilibrium;

$k_{2}-$ constant of the pseudo-2 ${ }^{\text {nd }}$ order kinetic model $\left(\mathrm{kg} \cdot \mathrm{mg}^{-1} \mathrm{~min}^{-1}\right)$.

Considering the boundary conditions $t=0 \rightarrow q=q_{0}$, and at the moment $t \rightarrow q=q_{t}$, results the integral form of the pseudo- $2^{\text {nd }}$ kinetic order:

$\frac{1}{q^{*}-q_{t}}=\frac{1}{q^{*}-q_{0}}+k_{2} t$

which can be expressed in the linear form

$\frac{t}{q_{t}-q_{0}}=\frac{1}{k_{2}\left(q^{*}-q_{0}\right)^{2}}+\frac{1}{q^{*}-q_{0}} t$

Model parameters were calculated considering in equation (5') the variable changes $x$ $=t, \mathrm{y}=\frac{t}{q_{t}-q_{0}}$.

In order to determine the retention rate of the $\mathrm{Cd}^{2+}$ and of the $\mathrm{Cu}^{2+}$ in the soil, kinetic study was performed; at initial concentration $100 \mathrm{mg} / \mathrm{L}$ and two different $\mathrm{pH}$ (2 and 5.18) were chosen. The study was performed on a chernozem soil.

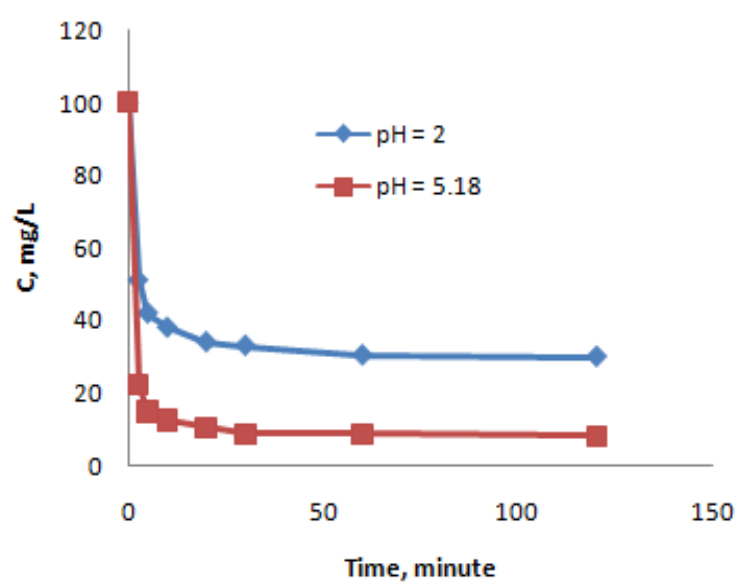

Figure 1 Variation concentration in the solution of the $\mathrm{Cd}^{2+}$ in time

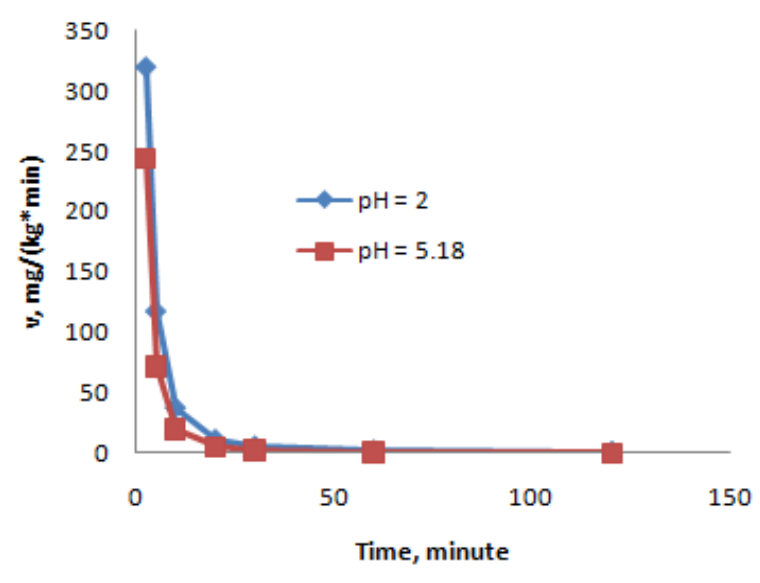

Figure 2 Variation, in time, of the sorption the $\mathrm{Cd}^{2+}$ in the soil

The experimental data regarding the retention kinetics of the $\mathrm{Cd}^{2+}$ cation at different $\mathrm{pH}$ solutions are shown in figure 1. The comparative kinetic data presented in figure 1 put in evidence the fact that the retention kinetics is differentiated, depending on the $\mathrm{pH}$ solution studied chernozem soil, under similar conditions. In both solutions can be observed a decrease in the concentrations of $\mathrm{Cd}^{2+}$ cations due to retention in soil. For low contact times, under the mentioned conditions, the retention rate of the $\mathrm{Cd}^{2+}$ cation is relatively high for all solutions. Increasing the contact time (over $10 \mathrm{~min}$ ), the retention rate decreases. Thus, after 30 minutes, the retention rate reaches a value of $4.74 \mathrm{mg} / \mathrm{kg}^{*} \min$. 


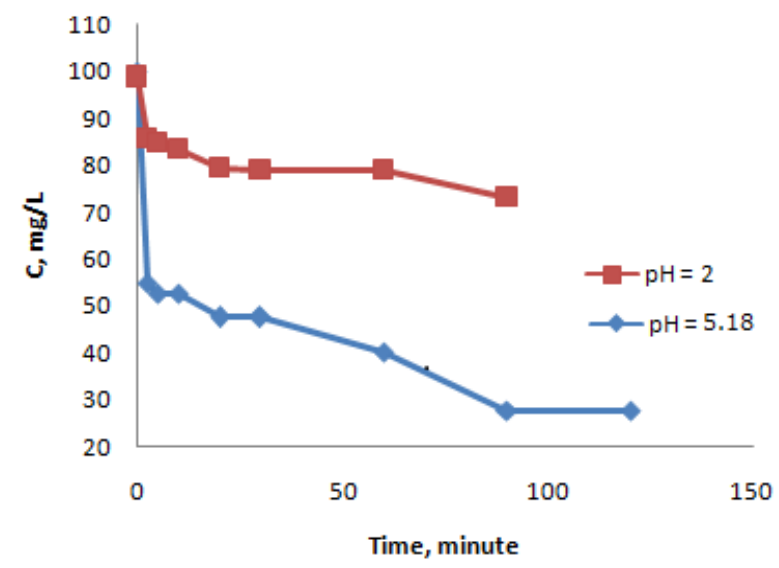

Figure 3 Variation, in time, of the $\mathrm{Cu}^{2+}$ rate of concentration in the solution

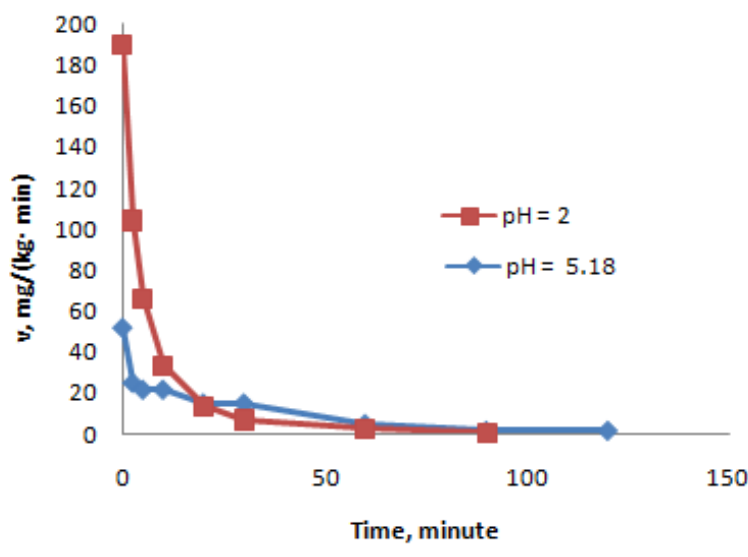

Figure 4 Variation, in time, of the sorption the $\mathrm{Cu}^{2+}$ in the soil

The kinetic curves shown in figure 3 point out a slow decrease of the concentration of $\mathrm{Cu}^{2+}$ in the solution, in the time interval 0 - 120 minutes. For low contact times, under the mentioned conditions, it can be notice that for the soil, for a concentration of 100 $\mathrm{mg} / \mathrm{L}$, during the first 10 minutes, there is a decrease of the $\mathrm{Cu}^{2+}$ concentration in the water of about $50 \%$ at $\mathrm{pH}=5$ and $20 \%$ at $\mathrm{pH}=2$.

The kinetic curves presented in figure 4 show a high value of the retention rate of the $\mathrm{Cu}^{2+}$ in the initial stage of the process. The comparative kinetic data shown in figure 4 show the fact that the ionic exchange kinetics is differentiated for the studied soil profiles (under similar conditions, the retention speed is higher in the case of $\mathrm{Cu}^{2+}$ retention considering the $\mathrm{pH}=5.18$ at an initial solution concentration of $100.0 \mathrm{mg} / \mathrm{L}$ ). Regression results, calculated by using Eq. (1 and 2) are presented in Table 3.

Table 3 Regression calculations results

\begin{tabular}{|c|c|c|c|c|c|}
\hline \multirow[b]{2}{*}{ Model } & \multirow{2}{*}{$\begin{array}{l}\text { cation } \\
\mathrm{pH}\end{array}$} & \multicolumn{2}{|l|}{$\mathrm{Cd}^{2+}$} & \multicolumn{2}{|l|}{$\mathrm{Cu}^{2+}$} \\
\hline & & 2 & 5.18 & 2 & 5.18 \\
\hline \multirow{5}{*}{ 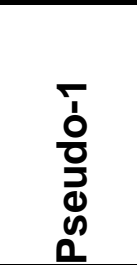 } & slope & -0.2407 & -0.3081 & -0.2797 & -0.3887 \\
\hline & intercept & 0.3207 & 2.0810 & 2.3724 & 2.9072 \\
\hline & $R^{2}$ & 0.9684 & 0.8367 & 0.9747 & 0.7979 \\
\hline & $k_{1}, \min ^{-1}$ & 0.2697 & 0.3181 & 0.2927 & 0.3957 \\
\hline & $\Delta q(\%)$ & $1.165 \%$ & $5.214 \%$ & $3.885 \%$ & $5.105 \%$ \\
\hline \multirow{6}{*}{ 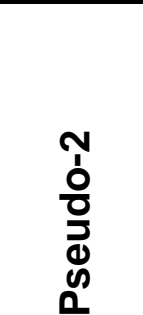 } & slope & 0.0999 & 0.0495 & 0.0354 & 0.0241 \\
\hline & intercept & 0.0248 & 0.0293 & 0.0155 & 0.0063 \\
\hline & $R^{2}$ & 0.9999 & 0.9997 & 0.9997 & 0.9999 \\
\hline & $\mathrm{k}_{2}, \mathrm{~kg} \cdot \mathrm{mg}^{-1} \cdot \mathrm{min}^{-1}$ & 0.6692 & 0.1303 & 0.0808 & 0.0864 \\
\hline & $q^{\star}, \mathrm{mg} \cdot \mathrm{kg}^{-1}$ & 105.62 & 115.79 & 95.24 & 92.93 \\
\hline & $\Delta q(\%)$ & $4.207 \%$ & $5.596 \%$ & $6.890 \%$ & $2.105 \%$ \\
\hline
\end{tabular}

The $R^{2}$ values presented in Table 1 show that the pseudo-2 order kinetic model, presented in Eq. (2), can be successfully used to describe the integral kinetic curves $q(t)$ for all experimental data sets. Thus the pseudo- 2 order model parameters, $k 2$ and $q^{*}$, were used to calculate the ion exchange rates. This way were established individual datasets $(c, q, r)$ and it was tried to establish a mathematic dependence of ion 
exchange rate, $r$, on the solute concentration in aqueous phase, $c$, respectively in soil, $q$.

\section{Conclusions}

From kinetic study of $\mathrm{Cd}^{2+}$ and $\mathrm{Cu}^{2+}$ retention, it has been concluded that for both metals, retention rate is increasing while ions concentrations in aqueous solution are greater. Based on experimental data, variation in time of $\mathrm{Cd}^{2+}$ and $\mathrm{Cu}^{2+}$ concentration in aqueous solution has been presented.

The $\mathrm{Cd}^{2+}$ retention rates are similar in the first 5 minutes at both $\mathrm{pH}$ values. In the first 10 minutes, sorption rate achieves high values, than retention rate decreases continuously in time. Regarding $\mathrm{Cu}^{2+}$ retention, one can observe that sorption rates have small values, as long as in the deepest profile, $\mathrm{Cu}^{2+}$ retention occurs at a higher rate. This trend is due to precipitation processes, which lead to mobile $\mathrm{Cu}^{2+}$ transition into low soluble forms.

While comparing retention of both $\mathrm{Cu}^{2+}$ and $\mathrm{Cd}^{2+}$, a similarity has been observed. Thus, for the $\mathrm{pH}=2$, a lower retention rate and a higher concentration in aqueous phase have been observed. In consequence, it has been concluded that retention rate for both $\mathrm{Cd}^{2+}$ and $\mathrm{Cu}^{2+}$ increases while soil depth increases. By analyzing sorption rates, it has been observed that $\mathrm{Cd}^{2+}$ sorption occurs faster than in the case of $\mathrm{Cu}^{2+}$.

Mathematical description of heavy metals behavior in water bodies can represent a useful tool to predict the long term consequences of a major accidental discharge. In this paper, the authors intended to establish a correlation between $\mathrm{Cd}^{2+} / \mathrm{Cu}^{2+}$ concentration in aqueous phase and sediment, and $\mathrm{Cd}^{2+} / \mathrm{Cu}^{2+}$ retention rate, in order to assess $\mathrm{Cd}^{2+} / \mathrm{Cu}^{2+}$ behavior and its spatial and temporal distribution.

Results show that, regardless the high level of initial soil contamination, $\mathrm{Cd}^{2+} / \mathrm{Cu}^{2+}$ retention process is a very fast one, the largest amounts of $\mathrm{Cd}^{2+} / \mathrm{Cu}^{2+}$ being retained in the first minutes after the phase contact.

The models were proposed to define the most appropriate way to determine the $\mathrm{Cd}^{2+} / \mathrm{Cu}^{2+}$ retention rate on soil. To achieve this goal, the Pseudo-1 ${ }^{\text {st }}$ order and Pseudo- $2^{\text {nd }}$ order were used.

Thus, the use of a Pseudo- $2^{\text {nd }}$ order model represents in a future research a good approach, as long as the Pearson correlation coefficients reach values in the range $0.84-0.90$.

\section{Acknowledgements}

The work has been funded by the Sectoral Operational Programme Human Resources Development 2007-2013 of the Ministry of European Funds through the Financial Agreement POSDRU/159/1.5/S/134398.

\section{References T}

[1] Benedetti A., Bertoldi S., F. Pinzari (1998)- Defining soil quality: introduction to round table in COST Actions 831, Joint WCs Meeting, Biotechnology of soil: monitoring conservation and remediation, 29-33.

[2] Chen J.M., Hao O.J., (1998) Microbial chromium (VI) reduction, Cri. Rev. Environ. Sci. Technol. 28 (3), 219-251

[3] Wang-Wang Tang, Guang-Ming Zeng, Ji-Lai Gong, Jie Liang, Piao Xu, Chang Zhang, Bin-Bin Huang, (2014), Impact of humic/fulvic acid on the removal of heavymetals fromaqueous solutions using nanomaterials: A review, Science of the Total Environment 468469, 1014-1027 
[4] Tang W.W., Zeng G.M., Gong J.L., Liu Y., Wang X.Y., Liu Y.Y., et al. (2012) Simultaneous adsorption of atrazine and $\mathrm{Cu}(\mathrm{II})$ from wastewater by magnetic multi-walled carbon nanotube., Chem Eng J 211-212, 470-8.

[5] FilipicM., (2012) Mechanisms of cadmium induced genomic instability. Mutat Res;733(1-2) 69-77.

[6] Rahman MS, Islam MR. (2009) Effects of $\mathrm{pH}$ on isotherms modeling for $\mathrm{Cu}$ (II) ions adsorption using maple wood sawdust., Chem Eng J; 149(1-3), 273-80.

[7] Chavez E., He Z.L., Stoffella P.J., Mylavarapu R.S., Li Y.C., Baligar V.C. (2016) Chemical speciation of cadmium: An approach to evaluate plant available cadmium in Ecuadorian soils under cacao production., Chemosphere 150, 57-62

[8] Hongying Li, Xinxin Yea, Zhigang Genga, Hongjian Zhoua, Xisheng Guo, Yunxia Zhanga, Huijun Zhaoa, Guozhong Wanga, (2016) The influence of biochar type on long-term stabilization for $\mathrm{Cd}$ and $\mathrm{Cu}$ in contaminated paddy soils, Journal of Hazardous Materials 304 40-48

[9] Cui H.B., Zhou J., Si Y.B., Mao J.D., Zhao Q.G., Fang G.D., Liang J.N., (2014) Immobilization of $\mathrm{Cu}$ and $\mathrm{Cd}$ in a contaminated soil: one- and four-year field effects, J. Soil Sediments 14 1397-1406.

[10] Li, Z.Y., Ma, Z.W., van der Kuijp, T.J., Yuan, Z.W., Huang, L., (2014). A review of soil heavy metal pollution from mines in China: pollution and health risk assessment. Sci. Total Environ. 468, 843-853.

[11] Cui H.B., Zhou J., Si Y.B., Mao J.D., Zhao Q.G., Fang G.D., Liang J.N., (2014) Immobilization of $\mathrm{Cu}$ and $\mathrm{Cd}$ in a contaminated soil: one- and four-year field effects, J. Soil Sediments 14 1397-1406.

[12] Cang L., Zhou D.M., Wang Q.Y., Wu D.Y., (2009) Effects of electrokinetic treatment of a heavy metal contaminated soil on soil enzyme activities, J. Hazard. Mater. 172 1602-1607. [13] Hang X., Wang H., Zhou J., Ma C., Du C., Chen X., (2009) Risk assessment of potentially toxic element pollution in soils and rice (Oryza sativa) in a typical area of the Yangtze River Delta, Environ. Pollut. 157 2542-2549.

[14] Ye X.X., Li H.Y., Ma Y.B., Wu L., Sun B., (2014) The bioaccumulation of Cd in rice grains in paddy soils as affected and predicted by soil properties, J. Soil Sediments 4 14071416.

[15] Liu J.G., Qian M., Cai G.L., Yang J.C., Zhu Q.S., (2007) Uptake and translocation of $\mathrm{Cd}$ in different rice cultivars and the relation with $\mathrm{Cd}$ accumulation in rice grain, J. Hazard. Mater. 143 443-447.

[16] Ye X.X., Kang S.H., Wang H.M., Li H.Y., Zhang Y.X., Wang G.Z., Zhao H.J., (2015) Modified natural diatomite and its enhanced immobilization of lead, copper and cadmium in simulated contaminated soils, J. Hazard. Mater. 289 210-218.

[17] Park J.H., Choppala G.K., Bolan N.S., Chung J.W., Chuasavathi T., (2011) Biochar reduces the bioavailability and phytotoxicity of heavy metals, Plant Soil 348 439-451.

[18] Brennan A., Jiménez E.M., Puschenreiter M., Alburquerque J.A., Switzer C., (2014) Effects of biochar amendment on root traits and contaminant availability of maize plants in a copper and arsenic impacted soil, Plant Soil 379 351-360.

[19] Xu D.Y., Zhao Y., Sun K., Gao B., Wang Z.Y., Jin J., Zhang Z.Y., Wang S.F., Yan Y., Liu X.T., Wu F. C., (2014) Cadmium adsorption on plant-and manure-derived biochar and biochar-amended sandy soils: impact of bulk and surface properties, Chemosphere 111320 326.

[20] Bian R.J., Joseph S., Cui L.Q., Pan G.X., Li L.Q., Liu X.Y., Zhang A.F., Rutlidge H., Wong S.W., Chia C., Marjo C., Gong B., Munroe P., Donne S., (2014) A three-year experiment confirms continuous immobilization of cadmium and lead in contaminated paddy field with biochar amendment, J. Hazard. Mater 272 121-128

[21] Orbuleţ O., Kreider, L, Modrogan C., Miron A., Apostol G., Costache C., Constantinescu I., „Application of Langmuir and Freundlich isotherms to phosphate sorption by soils: Modelling and Effects of $\mathrm{pH}$ ", The 8th International Simposium Prospects for the 3rd 
Millennium Agriculture, Cluj-Napoca (publicat în Bulletin of University of Agricultural Sciences and Veterinary Medicine Cluj-Napoca), ISSN 1843-5246, pag 146-153, octombrie 2009

[22] Modrogan C, Apostol D. G.i, Butucea O.D., Miron Al. R., Costache C., Kouachi R., (2013) Kinetic study of hexavalent chromium removal, from wastewaters by ion exchange, Environmental Engineering and Management Journal, May, Vol.12, No. 5, 929-935 